\title{
Trends in ozone levels and identification of visible injuries on agricultural crops in areas in the Metropolitan Zone of Mexico Valley
}

\author{
J. Cerón ${ }^{1}$, J. Ramírez ${ }^{2}$, B. Cárdenas ${ }^{3}$, V. Gutiérrez ${ }^{3}$, S. Blanco ${ }^{3}$, \\ R. Cerón ${ }^{1}$, J. Guerra ${ }^{1}$, R. Ramos ${ }^{4} \&$ A. Retama ${ }^{4}$ \\ ${ }^{1}$ Universidad Autónoma del Carmen, Facultad de Química, Mexico \\ ${ }^{2}$ Instituto de Meteorología de la República de Cuba, Cuba \\ ${ }^{3}$ Centro Nacional de Investigación y Capacitación Ambiental, Mexico \\ ${ }^{4}$ Dirección General de Gestión Ambiental del Aire, Mexico
}

\begin{abstract}
Measurements of ozone concentrations were carried out in the ambient air of agricultural areas of the Metropolitan Zone of the Valley of Mexico. Meteorological parameters, processes of synoptic scale and the possible damage to the agricultural crops were related to the ozone levels measured. The project was carried out in two campaigns: the first was carried out in the agricultural areas of the Parres, Tlahuac and San Luis, Xochimilco, in the Federal District from August 9 to August 28 of 2002; and the second was carried out in Huixquilucan, located at Mexico State, during June and July of 2003. The measurements were performed by continuous analyzers, whose principle of operation is the UV-Photometry. In the first campaign (2002), the analysis of the data showed maximum 1-hour concentrations of ozone up to $175 \mathrm{ppb}, 169 \mathrm{ppb}$, and $192.7 \mathrm{ppb}$ in Tlahuac, San Luis Xochimilco, and Parres, respectively. During the second campaign (2003), the maximum average 1-hour ozone concentrations found in Huixquilucan during June and July, were up to $172 \mathrm{ppb}$ and $213 \mathrm{ppb}$, respectively. It was demonstrated that in the study areas during 2002 and 2003, the 1-hour concentrations of ozone reached harmful values for the agricultural crops. In the agricultural areas of San Miguel de Topilejo, characteristic damages attributable to ozone were identified in potato and oat cultivations.
\end{abstract}

Keywords: ozone concentrations, impact on crops, foliar damage, Mexico. 


\section{Introduction}

Photo-oxidant compounds like ozone have been a cause of concern around the world during the last years due to their effects on vegetation [9]. There is evidence that high concentrations of ozone cause different effects on vegetation, including visible damages to the foliar tissues, decreases in yield and growth rates in plants and a high sensitivity to biotic and non-biotic stress factors [18].

Some research works about exposure of plants from different communities at realistic levels of ozone have been reported, to assess the sensitivity of specific species to this pollutant to determine threshold values of damage and to propose secondary standards for protection to the vegetation $[1,6,7,10,17]$.

In Mexico there are several studies about the assessment of the impacts of high ozone concentrations in some forested regions near Mexico City. The extensive forest decline in the mountains to the south-southwest of Mexico City has been associated with air pollution [2]. Symptoms of foliar photochemical injury to conifers and the local black cherry are severe in Desierto de los Leones, a protected area near the city [2, 3, 14, 16, 20]. However, injuries from air pollution to agricultural crops are less known [3, 13]. For this reason it is important to measure ozone concentrations in agricultural areas near Mexico City to determine if these concentrations reach values higher than those reported as dangerous for vegetation and to determine if these ozone levels affect the growth of cultivations in these regions. Likewise, it is important to correlate some meteorological phenomena in a synoptic scale to the ozone levels found in the study areas.

This study focuses on an analysis of ozone pollution in some agricultural areas near Mexico City, identifying ozone severe episodes and foliar injuries in specific species during August of 2002, and June and July of 2003.

\section{Materials and methods}

\subsection{Study area}

The first campaign of this study was carried out in agricultural areas of Parres, Tlalpan, Tlahuac and San Luis Xochimilco during August of 2002; and the second campaign was carried out in Huixquilucan, Mexico State during June and July of 2003. Table 1 gives a brief description of each monitoring site and the specific location of each monitoring site is shown in Figure 1.

\subsection{Methods}

For the current research, API model 400 ozone continuous analyzers were operated at each respective site. 10-min averaging time intervals were monitored and recorded in Parres, San Luis, and Huixquilucan. In the Automatic Atmospheric Monitoring Station of Tlahuac, 1-hr averages were monitored and recorded. All data sets were checked for anomalies and missing records. 
Anomalies caused by calibration procedures, power problems, and so on, were removed from the data sets before statistical analysis.

Table 1: $\quad$ Description of the study area.

\begin{tabular}{|c|c|}
\hline Monitoring Site & Description \\
\hline Parres, Tlalpan & $\begin{array}{l}\text { Located at } 19^{\circ} 17^{\prime} \mathrm{N} \text { and } 99^{\circ} 10^{\prime} \mathrm{W} \text {, ca. } 2800 \mathrm{~m} \text { with } \\
\text { an extension of } 308.71 \mathrm{~km}^{2} \text {. The main crops cultivated } \\
\text { in this area are oat, corn, and potato and there is an } \\
\text { extensive forested area. The exact monitoring site was } \\
\text { located in the facilities of the Natural Resources } \\
\text { Commission (CORENA) of the Federal District } \\
\text { Government. }\end{array}$ \\
\hline $\begin{array}{l}\text { San Luis, } \\
\text { Xochimilco }\end{array}$ & $\begin{array}{l}\text { Located at the Xochimilco Delegation, at } 19^{\circ} 16^{\prime} \mathrm{N} \\
\text { and } 99^{\circ} 06^{\prime} \mathrm{W} \text {, ca. } 2240 \mathrm{~m} \text { with an extension of } \\
119.16 \mathrm{~km}^{2}[15] \text {. In this area, the dominant crops } \\
\text { include corn, radish and gourd. The monitoring } \\
\text { equipment was located inside the facilities of the } \\
\text { Natural Resources Commission (CORENA) of the } \\
\text { Federal District Government. }\end{array}$ \\
\hline Tlahuac & $\begin{array}{l}\text { This specific monitoring site was located inside the } \\
\text { Automatic Atmospheric Monitoring Station of } \\
\text { Tlahuac, which belongs to the Automatic Atmospheric } \\
\text { Monitoring Red (RAMA) of the Federal District } \\
\text { Government at } 19^{\circ} 17^{\prime} \mathrm{N} \text { and } 99^{\circ} 00^{\prime} \mathrm{W} \text {. This area has } \\
\text { a territorial extension of } 86.36 \mathrm{~km} 2 \text { and } 60^{\circ} \text { of the } \\
\text { ecological conservation soils are dedicated to } \\
\text { agricultural activities [15]. }\end{array}$ \\
\hline $\begin{array}{l}\text { Huixquilucan, } \\
\text { Mexico State }\end{array}$ & $\begin{array}{l}\text { The monitoring equipment was located inside the } \\
\text { facilities of the Family Integral Development (DIF) of } \\
\text { the Federal District Government in San Cristobal } \\
\text { town at } 19^{\circ} 24^{\prime} \mathrm{N} \text { and } 99^{\circ} 18^{\prime} \mathrm{W} \text {. }\end{array}$ \\
\hline
\end{tabular}

During the monitoring period, meteorological parameters were measured by a portable meteorological station (Met One, Automet model) in Parres, San Luis and Huixquilucan. To determine ozone threshold values, 8-hr averages and 1-hr averages values were computed to determine how many times the air quality standard was exceeded during both campaigns. Likewise, ozone maximum concentration values were identified in each site. Additionally, it was carried out a synoptic meteorology analysis. Wind fields at the heights of 8000, 9000 and $10,000 \mathrm{ft}$ were used. For the first campaign were used maps developed by the Automatic Atmospheric Monitoring Red (RAMA) of the Federal District Government at 12:00 Z (07:00 hr local time) and for the second, were used the maps developed by the Meteorological Service of Cuba, at 12:00 Z, 18:00 Z and 00:00 Z. Additionally during the observation on the ozone effects an adjacent area covered by pine forest was evaluated to know the health condition during 
July of 2003, because damage caused by parasitic plants was observed, the 6class rating system proposed [11] was used to evaluate the infection level, the live crown is visually divided into thirds, each third is rated as zero for no mistletoe visible, one when less half of the branches infected or 2 more than half of the branches infected, rating of each third and then added to obtain a total for the tree [12].

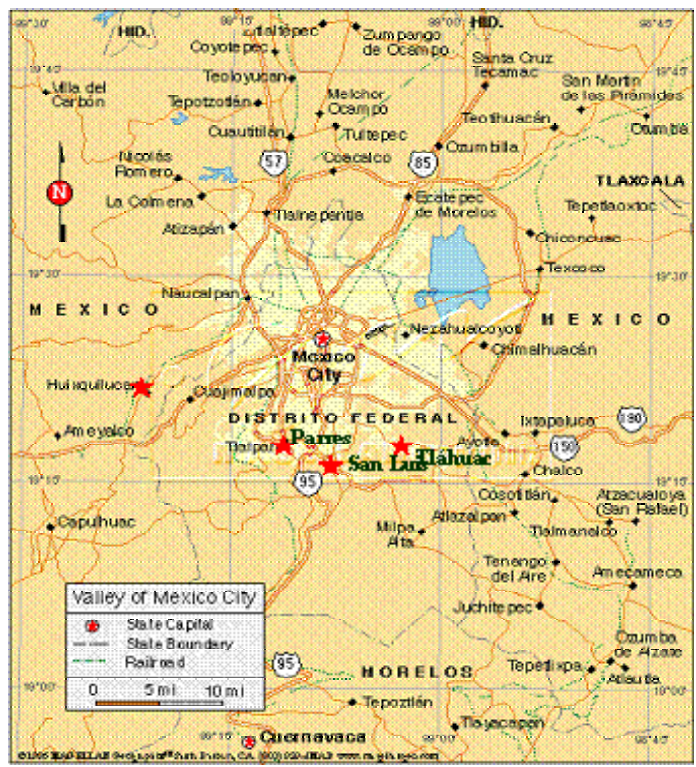

Figure 1: $\quad$ Location of monitoring sites in Mexico Valley.

An analyses correlation based on the data obtained from August 9 to 23, 2003, was made with the SAS program [19] from the averages obtained of the lectures hourly from 10:00 to 18:00 hours in Parres, San Luis, and Huixquilucan.

\section{Results and discussion}

During the first campaign (from August 9 to August 28, 2002) ozone maximum concentrations of 175 and $161 \mathrm{ppb}$ were observed in Tlahuac and San Luis, respectively, On the other hand, in Parres, a maximum value of $187 \mathrm{ppb}$ was registered (Figure 2). During the second campaign (from June 20 to July 14, 2003) ozone maximum concentrations values of $172 \mathrm{ppb}$ and $213 \mathrm{ppb}$ were found in Huixquilucan during June and July, respectively (Figure 3).

These values may cause severe damages to vegetation, and human health could be in risk, even when these sites are located far away from the center of Mexico City. It is possible that these ozone levels have their origin from transport of air pollutants from Mexico City. According these results, a classification was developed to indicate the air quality in agricultural areas 
considered in this study. When ozone levels were higher than $80 \mathrm{ppb}$ during eight continuous hours, air quality condition was classified as "an unacceptable condition"; whereas when ozone levels were lesser than $80 \mathrm{ppb}$, air quality condition was classified as "an acceptable condition".
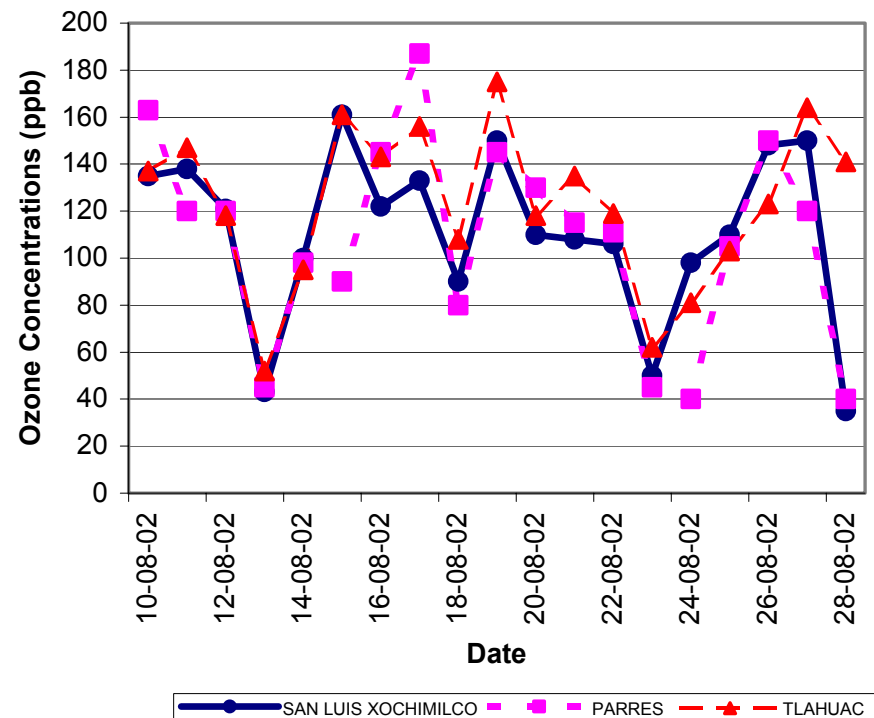

Figure 2: Daily maximum ozone levels during the first campaign.

In addition, it was registered the times when the air quality standard was exceeded in each site. The Mexican air quality standard [21] sets an 8-hr average concentration value of $80 \mathrm{ppb}$ and a 1 -hr average concentration value of $110 \mathrm{ppb}$. These values must not be exceeded more than once in a year. In Table 2, the classification of the air quality conditions is shown for each monitoring site.

Meteorological phenomena in a synoptic scale and local meteorology are related with pollutants dispersion in great urban centers where they are emitted as primary pollutants or formed as secondary pollutants, and also in agricultural zones, where these pollutants are transported from the urban centers.

During the first campaign, it was observed a relationship between hourly maximum ozone concentrations and meteorology, both, in a synoptic and local scales. In August 10, 2002, ozone levels kept under 10 ppb during the early morning (Figure 4), with a sustained variability of winds all the time. At 10:00 hrs, wind came from the north, and at this time, ozone concentrations increased, exceeding the threshold value to protect vegetation against damage for exposure to this pollutant. This wind direction kept sustained during seven hours, after this time period, once again it was observed a variability of winds, and ozone concentrations decreased. During the first campaign, according to figure 5, it can be observed that the wind during August 10, 2002, was due to a tropical wave located over Istmo de Tehuantepec causing that the wind fluxes over Mexico 
Valley came from northwest and blew to southeast with a speed of $10 \mathrm{~km} \mathrm{~h}^{-1}$ $\left(2.7 \mathrm{~m} \mathrm{~s}^{-1}\right)$ transporting air masses from urban zones toward the study area.

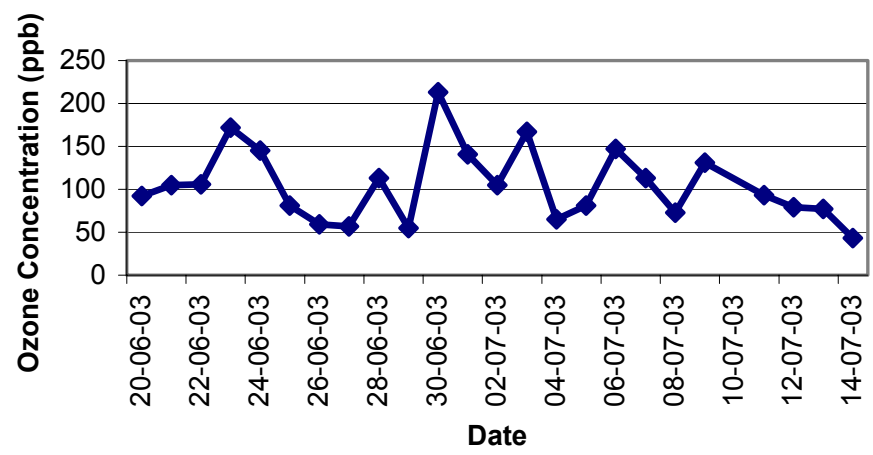

Figure 3: Daily maximum ozone levels during the second campaign.

Table 2: Classification of the air quality conditions for each monitoring site.

\begin{tabular}{|c|l|c|c|c|}
\hline \multirow{2}{*}{$\begin{array}{c}\text { Monitoring } \\
\text { Site }\end{array}$} & $\begin{array}{l}\text { Unacceptable } \\
\text { Conditions } \\
\text { Percentage }\end{array}$ & $\begin{array}{c}\text { Acceptable } \\
\text { Conditions } \\
\text { Percentage }\end{array}$ & $\begin{array}{c}\text { Clatification of the Air Quality Conditions } \\
\text { percentage } \\
\text { that exceeded } \\
\text { 1-hr average } \\
\text { concentration } \\
\text { value }\end{array}$ & $\begin{array}{c}\text { Data } \\
\text { percentage } \\
\text { that did not } \\
\text { exceed 1-hr } \\
\text { average } \\
\text { concentration } \\
\text { value }\end{array}$ \\
\hline \multicolumn{5}{|c|}{ First Monitoring Campaign ( August 9-August 28, 2002) } \\
\hline Tlahuac & 18.3333 & 81.6667 & 0.2092 & 99.7908 \\
\hline $\begin{array}{l}\text { San Luis, } \\
\text { Xochimilco }\end{array}$ & 6.8966 & 93.1034 & 4.3103 & 95.6897 \\
\hline Parres & 3.3898 & 96.6102 & 4.8729 & 95.1271 \\
\hline \multicolumn{6}{|c|}{ Second Monitoring Campaign (June 20- July 14, 2003) } \\
\hline $\begin{array}{l}\text { Huixquilucan, } \\
\text { Mexico State }\end{array}$ & 8.1301 & 91.8699 & 2.7439 & 97.2561 \\
\hline
\end{tabular}

The sites monitoring for ozone exposure indicate a 0.92 correlation coefficient this is a very good correlation between the conditions between San Luis and Parres while these two are not good related with the condition of Tlahuac with only 0.82 (R. $p<0.01$ )

During the morning, wind flow showed a calm period which prevailed and held high pollutants levels which transported from south-southwest to monitoring zone. For this reason, ozone concentrations reached maximum values exceeding $110 \mathrm{ppb}$ during for hours (Figure 7). 


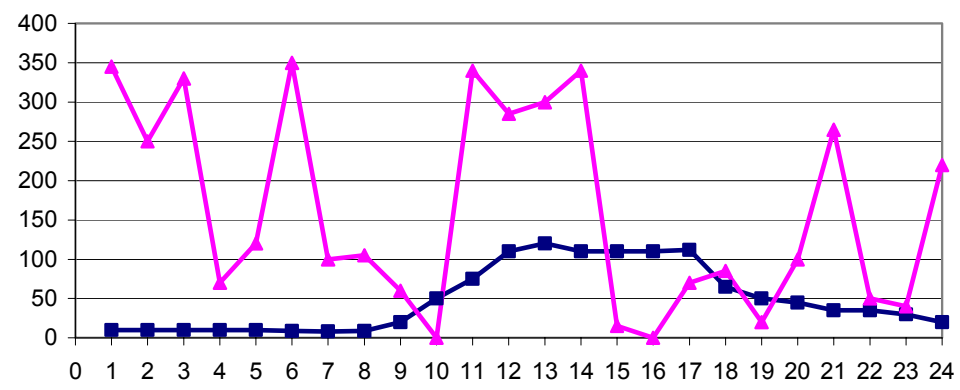

Hours

Ozone concentration $(\mathrm{ppb})-$ Wind direction (degrees)

Figure 4: Hourly ozone concentrations and wind direction at San LuisXochimilco during August 10, 2002.
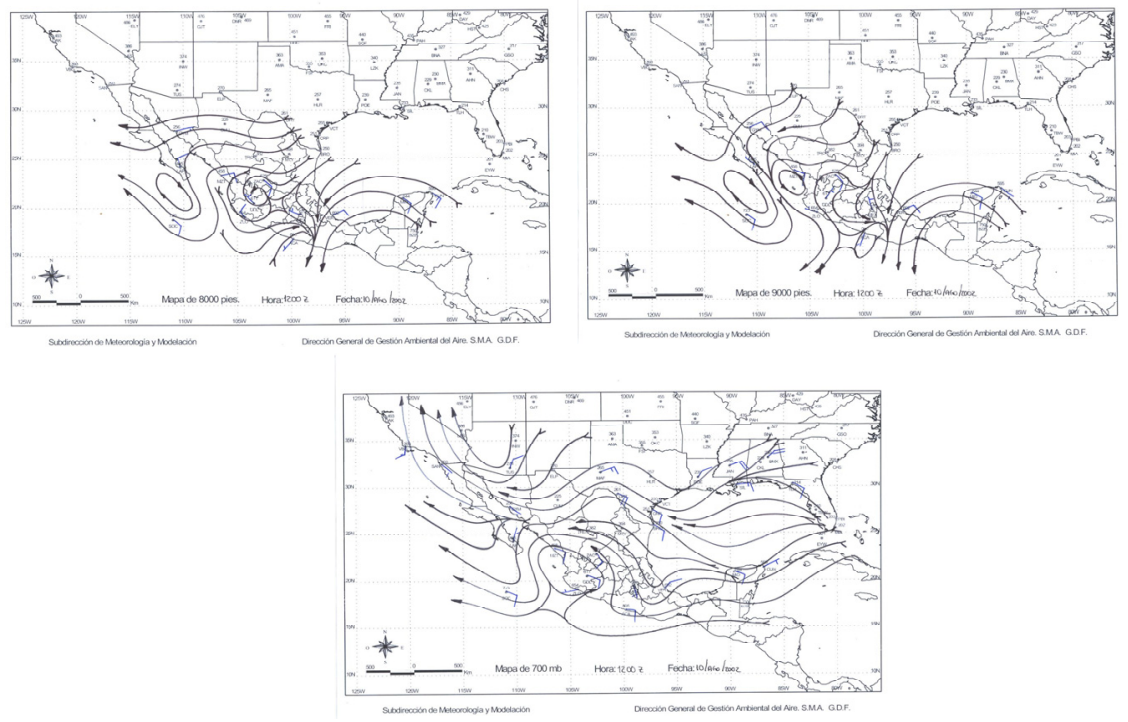

Figure 5: Wind Flux Analysis at $8000 \mathrm{ft}$ (left upper map), at $9000 \mathrm{ft}$ (right upper map) and $10000 \mathrm{ft}$ (bottom center map) of height at 12:00Z during August 10, 2002.

Some agricultural areas in San Miguel de Topilejo are located surrounding the site where continuous analyzers were located. In this zone, some agricultural fields with crops of potato, corn, gourd, radish and oat were selected to identify visible damages. The injuries observed in gourd leaves and potato (Figure 8) showed a good agreement with typical characteristics reported by other 
researchers for crops with wide leaves when these are exposed to high ozone levels $[2,3,6,7]$.
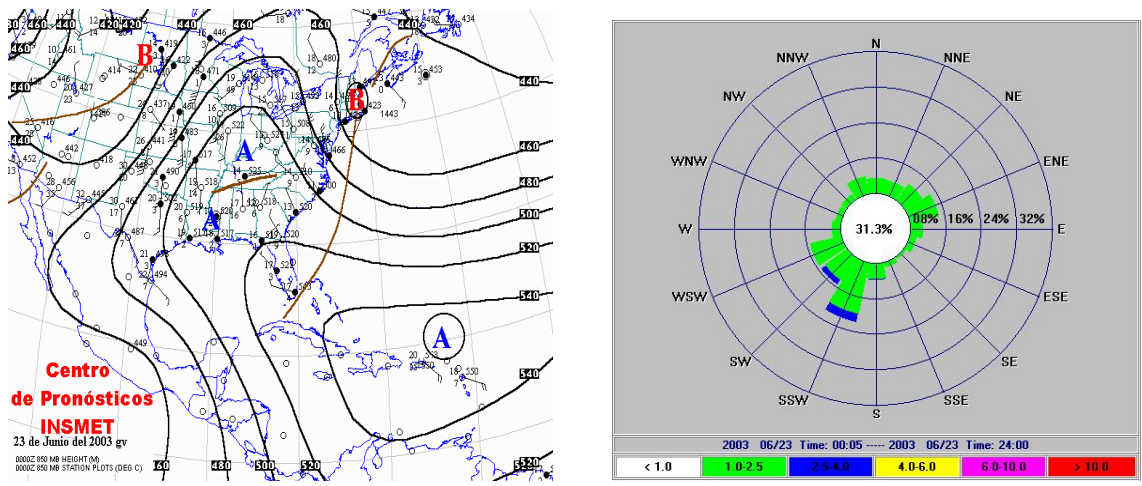

Figure 6: Synoptic analysis of upper air masses for June 23, 2003 for a height level of $850 \mathrm{hpa}$ at 0000Z, and local windrose for Huixquilucan, Mexico State.

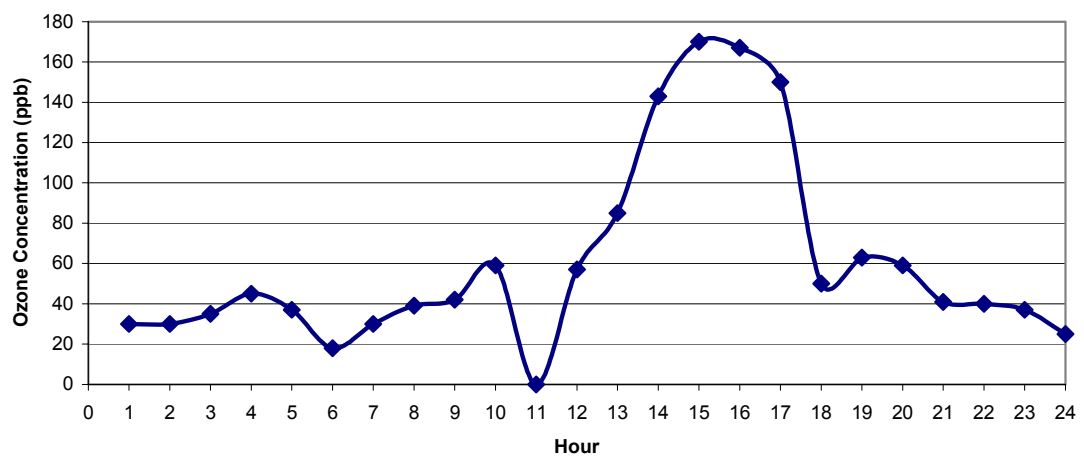

Figure 7: Hourly ozone concentrations at Huixquilucan, Mexico State during June 23, 2003.

The typical damage is irregular, bifacial, marginal and intervein, with necrotic areas, whitish dots, and chlorotic in aged leaves. When ozone levels are high, affected areas join each other to form greater burned areas and perforated zones. Similar damages were observed during the first and the second campaigns on crops of corn and oat.

The observed damages were attributable to high ozone concentrations; however, these damages contributed to the occurrence of pathogen organisms and the assessment of these indirect impacts requires additional research to determine their relative contribution to the total impact. In the forest area of Parres assessed to know the level infection of dwarf mistletoe was found and 
identified as Arceuthobium globosum Hawksworth and Wiens occurring on Pinus hartwegii Lindley. In the forest, from an area about 772.42 ha. a total of 40.17 ha. were evaluated a severely affected by the mistletoes as well as 156.42 ha. with moderate level according with the six class system, this indicates a very important occurrence of the dwarf mistletoe. Reports cited previously showed that in the Mexico city valley, there are some forested areas covered by this specific pine $P$. hartwegii, distributed mainly in high elevation area and exposed to ozone from the Mexico city, the air pollution can predispose to dwarf mistletoe infection [5].

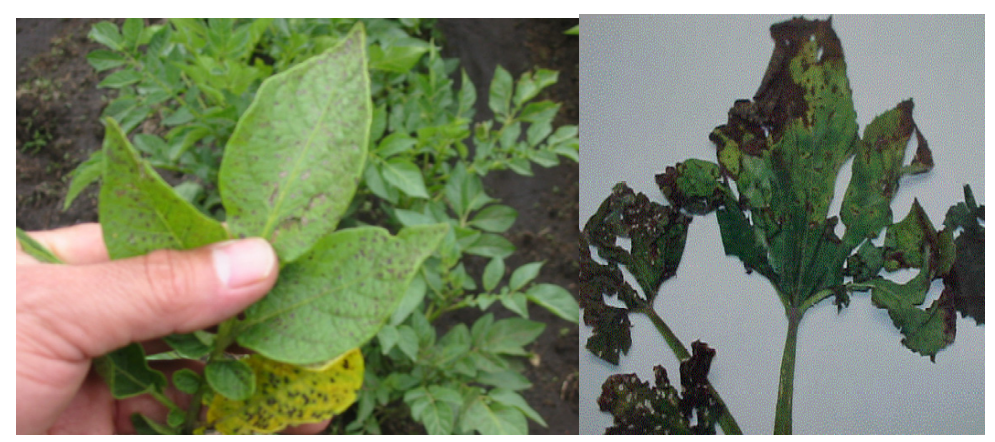

Figure 8: Visible Injuries due high ozone levels over agricultural crops of potato (left) and gourd (right).

Also some insect forest that affect the pines when they are considered as weakly trees especially bark beetles (Dendroctonus spp and Pythiopthorus mexicanus) were identified associated with the pines affected by mistletoes [8].

\section{Conclusions}

In agricultural areas of Xochimilco, Parres, Tlahuac and Huixquilucan, the ozone levels reached values higher than those reported as harmful for agricultural crops. From synoptic meteorological maps and local meteorology, it could be conclude that air masses were transported from Mexico City toward rural zones in the surroundings of Mexico State, suggesting that ozone was transported, and that the high ozone levels resulting caused injuries to agricultural crops, especially to sensible species like potato, gourd, corn and oat. Visible injuries identified showed a good agreement with those reported in other countries for sensitive crops exposed to ozone.

\section{Acknowledgements}

We acknowledge the technical support from the OPS (Pan-American Organization of Health) and the technical collaboration from CENICA (National Center for Research and Environmental Training). 


\section{References}

[1] Ashmore, M.R., Dalpra, C., \& Tickle, A.K., Effects of ozone and calcium nutrition on native plant species. In Air Pollution and Ecosystems, ed. P. Mathy. Reidel Publishing Company, Dordrecht, The Netherlands, pp. 647-652. 1987.

[2] Bauer, L.I. \& Krupta, S.V. The Valley of México: summary of observational studies on its air quality and effects on vegetation. Enviromental Pollution, 65, pp. 109-118. 1990.

[3] Bauer, L.I., Hernandez, T., \& Manning, W.J. Ozone causes needle injury and tree decline in Pinus Hartwegii at high altitudes in the mountains around Mexico City. Journal Air Pollution Control Association, 65, pp. 109-118. 1985.

[4] Bauer, L.I. \& Hernández, T. Contaminación: una amenaza para la vegetación en México. Colegio de Postgraduados. Centro de Fitopatología. Chapingo, Estado de México, México, pp. 13-22. 1986.

[5] Bauer, M de L.; Hernández Tejeda T. and D. Alvarado Rosales. 1987. Forest decline in southern areas of México City. In Proceedings XIV International Botanic Congress. July 24 August 1. Berlin, Germany 404.

[6] Bermejo, V., Gimeno, B.S., Sanz de la Torre, J., \& Gil, J.M. Assessment of the ozone sensitivity of 22 native plant species from Mediterranean annual pastures based on visible injury. Atmospheric Environment, 37, pp. 4667-4677. 2003.

[7] Bergmann, E., Bender, J., \& Weigel, H.J. Ozone threshold doses and exposure-response relationships for the development of ozone injury symptoms in wild plant species. New Phytolgyst, 144, pp. 423-435. 1999.

[8] Cibrián T. D.; Méndez, M. J.; Campos B. R. Yates III, H. O, and J. Flores. 1995. Insectos forestales de México. Esp. Pub. No. 6. North America Forestry Commission FAO 453 p.

[9] Colbeck, A.R. Air pollution by photochemical oxidants, Elsevier, Amsterdam. 1994.

[10] Franzaring, J., Tonneijck, A.E.G., Koijman, A.W.N., \& Dueck, Th. A. Growth responses to ozone in plant species from wetlands. Environmental and Experimental Botany, 44, pp. 39-48. 2000.

[11] Hawksworth, F. G. 1977. The 6-class Dwarf mistletoe rating system. USDA. Forest Service RM-48.

[12] Hawksworth, F. G. and D. Wiens. 1996. Dwarf mistletoes: biology, pathology and sustematichs. Agriculture handbook. 709. USDA. Forest Service. Washington, USA. 410 p.

[13] Hernández,. T., \& Bauer, M. La Supervivencia Vegetal ante la Contaminación Atmosférica. Colegio de Postgraduados. Chapingo. Edo, de México. 1989.

[14] Hernández, T., \& Nieto, C. Effects of oxidant air pollution on Pinus Maximartinez II Rzedowski in México City Region. Environmental Pollution, 26, pp. 79-83. 1995.

[15] INEGI. Estadística del Medio Ambiente. Tomo II. 1999. 
[16] Miller, P., Bauer, M.I., Quevedo, A., \& Hernández, T. Comparison of ozone exposure characteristics in forested regions near México City and Los Angeles. Atmospheric Environment, 28, pp. 141-148. 1994.

[17] Pleijel, H. \& Danielsson, H. Growth of 27 herbs and grasses in relation to ozone exposure and plant strategy. New Phytologist, 135, pp. 361-367. 1997.

[18] Sanz Sánchez M. José; Gerardo Sánchez Peña; Vicent Calatayud Lorente; M. Teresa Minaya Gallego; Julia Cerveró Albert. (2001). La Contaminación Atmosférica en los Bosques: Guía para la identificación de daños visibles causados por Ozono. Ministerio de Medio Ambiente. Dirección General de Conservación de la Naturaleza. Editado por el Organismo Autónomo de Parques Nacionales. Madrid, España. 2001.

[19] SAS Institute. 1985. SAS/STAT Guide for personal computers, version 6. United States.

[20] Zambrano, A. \& Nash, T.H. Lichen Responses to short term transplantation in Desierto de Los Leones, Mexico, City. Environmental Pollution, 107, pp. 407-412. 2000.

[21] NOM-020-SSA1-1993. Norma Oficial Mexicana de salud ambiental. Criterios para evaluar la calidad del aire ambiente con respecto al ozono. Secretaría de Salud. México. 1993. 